\title{
The effect of payroll taxes on employment and wages under high labor informality
}

\author{
Arturo Antón
}

\section{Correspondence:}

arturo.anton@cide.edu

Centro de Investigación y Docencia

Económicas (CIDE), Carretera

Mexico-Toluca 3655, Mexico City

01210, Mexico

\begin{abstract}
This paper evaluates the effects of a fall in payroll taxes on employment and wages in the presence of high labor informality. For that purpose, the paper examines a recently approved tax reform in Colombia especially targeted to promote labor formality. The model suggests that the reform would increase total employment by between 0.3 to 0.5 percent and formal employment by between 3.4 to 3.7 percent over the pre-reform scenario. In addition, formal wage rates would increase by 4.9 percent as a result of the reform. This finding suggests that the pass-through effect in labor markets may be large in these economies.
\end{abstract}

JEL codes: E62; H26; J21; O170

Keywords: Labor informality; Payroll taxes; Tax incidence

\section{Introduction}

Informality is a widespread phenomenon, especially in developing countries. As discussed in detailed by Schneider and Enste (2000), informality may be explained by many factors. In several studies, the burden of taxes and social insurance contributions are typically identified as one of the most important factors for explaining informality ${ }^{1}$. Based on this finding, governments are sometimes motivated to decrease taxes, particularly payroll taxes, to promote labor formality and thus provide social insurance services for a larger share of the population. This may be an especially demanding issue for some regions in the world. For example, Gasparini and Tornalli (2009) estimate that approximately 56 percent of wage earners in Latin America are informal in the sense that they do not pay labor taxes in exchange for social insurance services such as health and pensions.

The goal of this paper is to evaluate the effects of a fall in payroll taxes on labor markets with high labor informality. In this regard, the recently approved tax reform in Colombia provides an interesting case study. With the aim of increasing labor formality, the government introduced a series of changes in the Colombian tax code in 2012, which included a 13.5 percentage point decrease in non-wage labor costs and a partial shift of the tax base from labor to corporate income to finance social programs ${ }^{2}$. The Colombian case is interesting for two reasons. First, non-wage labor costs are very high: previous to the 2012 reform, they accounted for more than 60 percent of the average wage rate (Hernández, 2012; Moller, 2012). Second, the share of informal workers is also high, regardless of the definition used, and ranges from 56 to 67 percent of the total workforce (Bernal, 2009; Mondragón-Vélez et al. 2010).

(C) 2014 Antón; licensee Springer. This is an Open Access article distributed under the terms of the Creative Commons Attribution License (http://creativecommons.org/licenses/by/4.0), which permits unrestricted use, distribution, and reproduction in any medium, provided the original work is properly credited. 
Evaluating the effects of payroll taxes on labor markets is not an easy task because there are several factors that need to be taken into account. As noted by Summers (1989) and Farné and Rodríguez (2013) among others, there are at least five issues that should be addressed to appropriately analyze the effects of payroll taxes: (1) the labor demand elasticity; (2) the labor supply elasticity; (3) the worker's valuation of the social insurance benefits financed through payroll taxes; (4) the presence of a binding minimum wage; and (5) the bargaining power of workers in the labor market. An additional element of analysis to be considered especially for developing countries is the existence of a significant fraction of informal workers in the labor market. Typically, the literature incorporates only some of the factors mentioned above into the analysis. In contrast, the model presented in this paper addresses many of the relevant factors listed, such as labor demand and supply equations derived from first principles, the valuation of worker's benefits financed through payroll taxes, and the distinction between formal and informal workers. In this manner, the present model may offer some additional insights not previously considered in the literature.

In particular, this paper presents a dynamic, general equilibrium model with occupational choice, tax evasion and informality. In the model, household members may choose among three alternative occupations: salaried worker, own-account or employee. This specification is important because own-account workers represent a significant share of the work force in developing countries and are usually associated with informal labor (see, for example, Gollin, 2008). As will be clear from the discussion of the next section, the modelling of own-account workers is typically ignored in the analysis of payroll taxes and labor markets. The model also features endogenous tax evasion: firms may optimally choose to avoid paying taxes, including payroll taxes. In this manner, a firm must choose not only how many workers to hire but also the mix of formal and informal workers. Thus, labor informality endogenously arises when the firm chooses not to pay labor taxes for some of its workers. As detailed below, the model also includes corporate income (CIT) and value-added (VAT) taxes to capture some features of the 2012 Colombian tax reform and the complexities of the tax code, especially for the VAT. Given its general equilibrium structure, the effects of a fiscal reform on both employment and wages may be appropriately evaluated from first principles.

The model is calibrated for the Colombian economy and used to simulate the effects of the 2012 tax reform on occupational choices, employment and earnings. The results suggest that the tax reform would have a positive but small effect on total employment. Specifically, employment would increase between 0.3 and 0.5 percent compared to the pre-reform scenario. At the same time, the reform would bring a significant reallocation of labor across occupational choices and formality status. In particular, formal employment would increase between 3.4 and 3.7 percent of total employment, and informality would decrease between 2.9 and 3.4 percent. Interestingly, the model also suggests that the reform would bring an increase of 4.9 percent in the formal wage rate, net of taxes and transfers. This implies that formal workers may actually bear a significant share of the tax burden imposed by non-wage labor costs through lower wages.

The rest of the paper is divided as follows. Section 2 presents a review of the literature on payroll taxes and their effects on labor markets. Section 3 discusses the 2012 Colombian tax reform in some detail, particularly the changes related to payroll, corporate income, and value-added taxes. Sections 4 and 5 describe the model used to 
evaluate the effects of the tax reform and how it is calibrated to the Colombian data. Section 6 presents the results including a sensitivity analysis, and Section 7 concludes the paper.

\section{Literature review}

In this section, a selected literature review on the effect of payroll taxes on labor markets is discussed. Particular attention is given to the evidence from the Colombian case ${ }^{3}$.

The empirical evidence of the effects of payroll taxes on employment is mixed. Some studies use cross-country panels, which allow them to exploit both temporal and crosscountry variation in tax rates. Recent studies (Daveri et al. 2000; Blanchard and Wolfers, 2000; Heckman and Pages, 2004) find a significant negative impact of payroll taxes on employment, but Daveri et al. (2000) find no effects for a subsample of AngloSaxon and Nordic countries. In particular, Heckman and Pages (2004) find that a 10 percent increase in payroll taxes decreases employment by 10 percent in OECD countries and by 4.5 percent in Latin American countries. However, a major concern is that these studies may be subject to endogeneity problems to the extent that employment may determine tax rates. In addition, they may also suffer from omitted variable bias in the sense that both tax rates and employment may be correlated with other institutional factors. For this reason, some studies prefer to examine the evidence from a particular country by exploiting the variation in tax rates that apply differentially across groups of individuals, firms, or sectors.

The evidence within countries is also mixed. For example, Gruber (1994) finds no employment effects of mandated benefits in the U.S. A similar result is reported for Chile (Gruber, 1997) and Argentina (Cruces et al. 2010), where changes in payroll taxes do not have a significant effect on employment. In contrast, studies such as Katz (1998) for the U.S. and Kugler et al. (2002) for Spain find positive effects of payroll subsidies on employment ${ }^{4}$. In particular, Katz (1998) estimates that the Targeted Job Tax Credit (TJTC) program increased employment for disadvantaged 23- to 24-year-olds by 3.4 percentage points ${ }^{5}$. Kugler et al. (2002) report an increase in permanent employment for young workers and older workers by 2.6 and 2.1 percent, respectively ${ }^{6}$.

For the particular case of Colombia, there are at least four studies that examine the role of payroll taxes on employment. Bernal and Cárdenas (2003) estimate the wage elasticity of labor demand to quantify the effects of payroll taxation on employment. They consider a static and a dynamic version of their labor demand equation and use alternative data sources. In their estimates, labor is divided into qualified and nonqualified workers; however, it is not classified into formal and informal workers. When household data are used, the estimates for the static version of the model suggest that a 10 percent decrease in payroll taxes could result in a 4.5 and 5.1 percent increase in skilled and unskilled labor demand, respectively. This estimate is lower when the dynamic version is used instead: total labor demand would increase by 3.7 percent after a 10 percent decrease in payroll taxes.

Kugler and Kugler (2009) also estimate a labor demand equation for Colombia using data at the firm level from a manufacturing sector survey. This survey is applied to firms with more than 10 workers. The authors define formality in terms of whether an individual plant in their sample reports positive payroll taxes. Because all the plants in 
their sample report paying payroll taxes, all the employment is defined by the authors as formal ${ }^{7}$. Their results suggest that a 10 percent increase in the payroll tax reduces formal employment by between 4 and 5 percent, after controlling for the plants' characteristics.

In contrast to the previous studies based on labor demand estimates, Mondragón-Vélez et al. (2010) study the effect of non-wage labor costs on the probability of being informal. For that purpose, the authors propose a probit model that allows individual characteristics to be controlled for. They use household survey data for the major Colombian cities and consider alternative definitions for informality, including the definition by the national statistics office and a definition based on health insurance coverage ${ }^{8}$. Their results suggest that an increase of 10 percentage points in non-wage costs is associated with an increase of 5 to 8 percentage points in the probability of being informal, depending on the definition of informality.

Finally, Hernández (2012) evaluates the effect of eliminating parafiscales taxes on the labor market using a computable general equilibrium (CGE) model with unemployment ${ }^{9}$. Some of the exercises considered by the author are revenue-neutral in the sense that other taxes must be raised simultaneously to keep the government budget constraint balanced. If other taxes are raised, the effect of eliminating parafiscales taxes on employment is lower in the model. The author defines informality according to the criteria used by the national statistics office. The results suggest that eliminating parafiscales taxes would increase formal employment between 5.1 and 7.4 percent relative to its benchmark level, and decrease informal employment between 1.4 and 4.2 percent. It would also lead to a decrease in the unemployment rate of at most 0.2 percentage points, which suggests that the positive effect on total employment would be small.

The second issue of interest is the effect of changes in payroll taxes on wages. As is well known, a payroll tax introduces a wedge between the equilibrium wage rate with no taxes and the after-tax wage rate received by workers. This wedge is the share of the payroll tax that the worker ends up paying through a lower wage rate, which is the so-called passthrough effect. The size of the pass-through effect depends on the relative importance of the factors mentioned above ${ }^{10}$. If the pass-through effect is large, it means that a decrease in payroll taxes will be translated into a large - but less than proportional - increase in wages.

Given that the pass-through effect is intrinsically linked to employment, it is not surprising that the empirical evidence available on this issue is also mixed. For the case of the U.S. and Chile, Gruber $(1994,1997)$ finds a large pass-through effect and thus full wage shifting of employer contributions. In contrast, Heckman and Pagés (2004) report a zero pass-through for a sample of OECD countries. Estimates between these two extremes of the spectrum are also reported. In particular, Heckman and Pagés (2004) find a 36 percent pass-through for a sample of Latin American countries. Cruces et al. (2010) find that 55 percent of the payroll tax is shifted to workers in Argentina. Estrades and Terra (2011) estimate that a 20 percent decrease in payroll taxes would increase formal wages up to 1.3 percent in Uruguay.

For Colombia, the study of Kugler and Kugler (2009) reports that an increase of 10 percent in payroll taxes would decrease wages for formal workers between 1.4 and 2.3 percent. Interestingly, this result is roughly in line with the findings of Heckman and Pagés (2004) for Latin American countries. Moreover, the CGE model of Hernández (2012) suggests that the elimination of parafiscales taxes would increase wages in the 
formal sector by between 0.5 and 2 percent. Similarly, wages in the informal sector would increase by between 1.5 and 5.2 percent.

To summarize, the evidence available for the effect of payroll taxes on employment and wages is mixed in general. For Colombia, the evidence suggests that changes in payroll taxes may have an effect on both employment and wages. This is true regardless of methodologies, data sources and definitions of informality. As mentioned in the introduction, there are several factors that ideally should be addressed when estimating such effects. In practice, it is not always possible to take into account all these factors. This is true for the estimates available in the literature, including those for Colombia. As discussed below, the model presented in Section 4 addresses many of the relevant factors listed, which may offer some useful insights to analyze the effect of payroll taxes on labor markets.

\section{The Colombian tax reform}

In recent years, Colombia has implemented a series of sound fiscal policies. As a result, the fiscal deficit of the government has decreased from 5 percent of GDP in 1999 to zero percent in 2008 (OECD, 2013) ${ }^{11}$. Notwithstanding this good fiscal record, the Colombian tax code faces several challenges. First, the redistributive effects of direct and indirect taxes cancel each other out, and monetary transfers are not sufficiently progressive (Moller, 2012; OECD, 2013). This is particularly striking given that, according to Moller (2012), Colombia has one of the most unequal income distributions in the world. Second, payroll taxes in Colombia are well above those registered in advanced countries (Kugler and Kugler, 2009). In particular, non-wage labor costs amount to more than 60 percent of the average wage rate (Hernández, 2012; Moller, 2012; see also Table 1 below). These taxes are imposed on employers to finance a series of social programs such as pensions, health benefits, in-kind transfers for lowincome households, training, and so forth. Third, labor informality in Colombia is high regardless of the criteria used to measure it and ranges from 56 to 67 percent of the total workforce (see, for example, Bernal, 2009, and Mondragón-Vélez et al. 2010). In fact, high non-wage costs and labor informality may be related to each other by discouraging employers to hire workers under all the requirements mandated by the law.

Table 1 Payroll tax components

\begin{tabular}{lc}
\hline Contribution for & \% of wage rate \\
\hline Pensions & 16 \\
Health care & 12.5 \\
Professional risks & 2 \\
Parafiscales & 2 \\
Training (SENA) & 2 \\
In-kind transfers (ICBF) & 3 \\
Compensation funds & 4 \\
Paid vacations & 4.2 \\
Severance pay & 8.3 \\
Mandatory bonuses & 8.3 \\
Total & $\mathbf{6 0 . 3}$ \\
\hline
\end{tabular}

Source: Vargas (2006) and Hernández (2012). 
In such a context, the government of Colombia presented a bill to the National Congress to reform the fiscal code in 2012. The fiscal reform was aimed at improving equity, promoting hiring in the formal sector, and simplifying the tax system to improve tax compliance. The bill was approved in December 2012.

Among the several changes in the Colombian fiscal code, two of them stand out. First, payroll taxes were decreased by 13.5 percentage points (pp) for workers earning up to 10 times the minimum wage. In particular, the wage-related contributions for training ( $2 \mathrm{pp}$ ), in-kind transfers for low-income households ( $3 \mathrm{pp}$ ) and health (8.5 pp) were eliminated. Given that total payroll taxes are estimated at 60.3 percent of the wage rate on average, such a reform implied a fall of 22.4 percent in the payroll tax. To compensate for the revenue lost, a new tax paid by firms called Contribución Empresarial para la Equidad (CREE or "fairness tax") was created. For practical purposes, the "fairness tax" is equivalent to a CIT of 8 percent ${ }^{12}$. To avoid increasing firms' tax burden, the CIT was simultaneously decreased from 33 to 25 percent. The "fairness tax" rate will be temporarily raised to 9 percent in the three years after the reform's approval, which means that it will return to its original rate of 8 percent in 2016. Overall, this reform implies a partial shifting of the tax base from labor to corporate income to finance the aforementioned social programs, but it leaves the total tax on corporate income approximately constant.

A second major change was the simplification of the structure of the value-added tax. In particular, the number of tax rates was decreased from seven to three $(0,5$, and 16 percent). For some goods and services, the tax rate increased with the reform but the result was just the opposite for some others, like agricultural inputs. At the same time, a new tax called "national consumption tax" was implemented. The new tax applies to the final sale of some particular goods and services such as prepared food, cell phone services, cars and ships, among others, at rates of 4,8 and 16 percent $^{13}$.

To evaluate the effects of the 2012 Colombian tax reform on labor markets, a dynamic macroeconomic model with a representative household, two types of firms, and a government is proposed and detailed in the next section ${ }^{14}$. In the model, some firms may optimally choose to hire formal and informal workers; some others are ownaccount firms which, for simplicity, are informal. This structure allows endogenously estimating the share of formal and informal workers. At the same time, the model computes equilibrium wage rates for formal and informal workers, given the tax rates. Thus, the effects of a fiscal reform on both employment and wages may be appropriately evaluated from first principles.

\section{The model}

This section presents a dynamic, general equilibrium model with occupational choice and labor informality. In particular, the occupational choice problem of Lucas (1978) is extended to include two sectors and three taxes in a tax evasion framework. The model has two sectors to capture the complexities of the VAT structure in Colombia. Here, sector 1 is labeled the "non-taxed" sector, which reflects the fact that several goods and services in Colombia were either exempt or paid a 0 or very low (1.6 percent) VAT rate under the tax structure previous to the 2012 fiscal reform. In contrast, sector 2 is labeled the "taxed" sector. The labels "taxed" and "non-taxed" refer to the VAT rate 
only. On the other hand, labor formality is defined in terms of access to contributory social insurance (CSI) services such as health and pensions ${ }^{15}$.

There is an infinitely lived, representative household populated by a continuum of individuals of mass 1 . There are two types of individuals, type 1 and type 2 . Each type has a mass $M_{j}$ in sector $j \in\{1,2\}$, with $M_{1}+M_{2}=1$, and each household member is endowed with $z_{j}$ units of managerial ability. Individuals draw their ability from two independent distributions according to their type. Abilities are distributed exogenously with support $Z_{j}=\left[\underline{z}_{j}, \bar{z}_{j}\right]$. Distribution functions are denoted by $G_{j}\left(z_{j}\right)$, and their corresponding densities are denoted by $g_{j}\left(z_{j}\right)$. For each type, an individual may have one out of three occupations: employee, own-account, or employer, depending on her managerial endowment $z_{j}$. This specification generates an occupational choice problem as explained below.

If the individual is a type $j$ own-account, output $y_{o j}$ is produced according to the following technology:

$$
y_{o j}=A_{o j} z_{j}^{1-\gamma}\left(f\left(k_{o j}, l_{o j}\right)\right)^{\gamma}=A_{o j} z_{j}^{1-\gamma}\left[\left(k_{o j}\right)^{1-\alpha}\left(l_{o j}\right)^{\alpha}\right]^{\gamma},
$$

where $\alpha \in(0,1)$ and $\gamma \in(0,1)$. Variables $k_{o j}$ and $l_{o j}$ denote capital and labor services of the own-account, and $A_{o j}$ is the level of technology.

If the individual is a type $j$ employer, output $y_{j}$ is given by the following production function:

$$
y_{j}=z_{j}^{1-\gamma}\left(f\left(k_{j}, l_{j}\right)\right)^{\gamma}=z_{j}^{1-\gamma}\left[\left(k_{j}\right)^{1-\alpha}\left(l_{j}\right)^{\alpha}\right]^{\gamma} .
$$

Both the own-account and employers produce goods in a perfectly competitive environment. Without loss of generality, good 2 is the numeraire.

\section{Taxes, tax evasion and transfers}

There are three taxes in the model: a value-added tax, $\tau_{y j}$, a CSI tax, $\tau_{l}$, and a corporate income tax, $\tau_{i}$. CSI taxes are also referred to simply as labor or payroll taxes. Here, the VAT varies between sectors, but the CSI and CIT taxes do not. The VAT is modeled as an output tax on establishments and the CIT as a tax on the rental rate of capital ${ }^{16}$. All three taxes are paid by the employers.

The tax enforcement authority is not able to enforce taxes fully; thus, firms have an incentive to evade taxes. Own-account workers face a zero probability of being detected, so they evade all taxes and face no distortions on their production decisions. The motivation is that their scale of production is so small that it is hard and costly for the tax authorities to monitor their activities.

In contrast, employers face a positive probability of being caught. They can decrease their labor tax burden by hiring informal labor $\left(l_{I}\right)$ at the wage rate $w_{I}$. The authority audits employers with a probability $q_{l}$ and imposes a fine proportional to the amount evaded $\sigma_{l} \tau_{l} w_{l} l_{l}$, with $\sigma_{l}>0$. Employers can also choose to evade the VAT. The authority audits employers with probability $q_{y}$ and imposes a fine proportional to the amount evaded $\sigma_{y} \tau_{y} y$, with $\sigma_{y}>0$.

Given this characterization, an employee is formal if the employer covers the payroll $\operatorname{tax} \tau_{l}$ for his/her employee; otherwise the employee is informal. Since own-account 
workers evade all taxes, they are also informal. Employers do not cover CSI taxes from their own labor services, so they are informal by assumption.

With regard to transfers, informal employees, own-account workers, and employers get non-contributory social insurance (NCSI) transfers, $T_{I}$, and formal employees get CSI transfers $T_{F}$. These transfers are non-contributory in the sense that they are financed from general revenues other than payroll taxes. In each period, the government budget constraint is satisfied so that the total transfers equal the total revenue.

\section{Individual earnings}

If an individual is a formal employee $l_{F}$ earnings are given by the wage rate $w_{F}$ plus the corresponding transfer $T_{F}$. If an employee is informal he/she receives $w_{I}+T_{I}$.

An own-account worker in sector $j$ makes profits $\pi_{o j}\left(w_{I}, r, p_{j}, z_{j}\right)$ according to:

$$
\max _{l_{o j}, k_{o j}}\left\{p_{j} A_{o j} z_{j}^{1-\gamma}\left(f\left(k_{o j}, l_{o j}\right)\right)^{\gamma}-r k_{o j}+w_{I}\left(\kappa-l_{o j}\right)\right\}
$$

where $p_{j}$ is the price of good $j$ and $r$ is the rental rate of capital. The restriction $0 \leq l_{o j} \leq$ $\kappa \leq 1$ is imposed to reflect that own-account workers lose a fraction $(1-\kappa)$ of their time endowment because they may simultaneously choose to perform managerial activities and provide labor services (Gollin, 2008). In addition to the NCSI transfer, ownaccount workers receive the rents from their firms plus the return to labor not used in their own productive units and offered to the market $\left(\kappa-l_{o j}\right)$. Accordingly, let $\left(l_{o j}\left(w_{I}, r\right.\right.$, $\left.\left.p_{j}, z_{j}\right), k_{o j}\left(w_{1}, r, p_{j}, z_{j}\right)\right)$ represent the optimal input choices of own-account workers.

Employers face two evasion decisions: whether to evade the VAT and how many formal and informal employees to hire. Define $\tau_{j}=\left(\tau_{y j}, \tau_{l}, \tau_{i}\right)$ as the vector that summarizes the tax system in sector $j$. The problem of sector $j$ 's employer is to maximize expected profits $\pi_{j}\left(w_{I}, w_{F}, r, p_{j}, z_{j}, \tau_{j}\right)$ :

$$
\max _{l_{l j}, l_{F}, k_{j}}\left\{\left(1-q_{y j} \sigma_{y} \tau_{y j}\right) p_{j} z_{j}^{1-\gamma}\left(f\left(k_{j}, l_{l j}+l_{F j}\right)\right)^{\gamma}-\left(1+\tau_{l}\right) w_{F} l_{F j}-\left(1+q_{l j} \sigma_{l} \tau_{l}\right) w_{I} l_{l j}-\left(1+\tau_{i}\right) r k_{j}\right\}
$$

There will be labor tax evasion as long as $\left(1+q_{l j} \sigma_{l} \tau_{l}\right) w_{I} \leq\left(1+\tau_{l}\right) w_{F}$ and there will be VAT evasion as long as $q_{y j} \sigma_{y}<1$. To obtain a non-degenerated distribution of informal labor across establishments in equilibrium, the probability $q_{l j}$ is assumed to be an increasing function of both the ability and the amount of informal workers hired: $q_{l j}\left(l_{l j}, z_{j}\right)$. In general, an employer will demand both formal and informal workers. However, the functional form for $q_{l j}\left(l_{I j}, z_{j}\right)$ guarantees that a manager with higher ability $z_{j}$ will demand relatively more formal workers because he/she will face a higher probability of being detected. Moreover, the probability of being detected when evading the VAT increases with ability: $q_{y j}\left(z_{j}\right)$. Therefore, firms with a larger entrepreneurial ability face a higher probability of being detected. This ensures that the set of VAT evaders is concentrated on small establishments.

Let $\left(l_{j}\left(w_{F} w_{I}, r, p_{j}, z_{j}, \tau_{j}\right), k_{j}\left(w_{F}, w_{I}, r, p_{j}, z_{j}, \tau_{j}\right)\right)$ be the optimal input decisions of fulltime entrepreneurs. It may be shown that the labor demand function depends negatively on each of the three taxes. 


\section{The household problem}

The representative household lives forever. The household derives utility from the consumption of each good $j, C_{j}$. Lifetime utility is represented by

$$
\sum_{t=0}^{\infty} \beta^{t} u\left(C_{1 t}, C_{2 t}\right)
$$

where $\beta \in(0,1)$ is the discount factor. The utility function $u\left(C_{1 t}, C_{2 t}\right)$ is increasing in both arguments, twice continuously differentiable and concave. In addition, the household is endowed with an initial capital stock $K_{0}$, and each period receives rental payments $r_{t} K_{t}$ from the firms. To simplify, good 1 is non-storable by assumption. In contrast, good 2 may be either consumed or invested. Capital depreciates at some constant rate $\delta \in(0,1)$. Letting $I_{t}$ denote gross investment, the law of motion of capital may thus be written as

$$
K_{t+1}=I_{t}+(1-\delta) K_{t}
$$

The representative household must choose sequences of consumption and capital as well as an occupation for each member to maximize lifetime utility subject to total income. The household must also choose the formality status of employees. This last choice is modeled with the variable $\eta \in(0,1)$, which represents the fraction of formal employees; the remaining fraction $1-\eta$ corresponds to informal employees.

If a household member becomes an employee, he/she supplies one unit of labor services to the market and receives the wage rate plus the corresponding transfer $T_{F}$ or $T_{I}$. This income must be compared with the after-transfer expected earnings from being an ownaccount worker or an employer. The occupational choice problem just described endogenously yields two thresholds for the entrepreneurial ability $z$ in each sector $j$, which are denoted as $\hat{z}_{1 j}$ and $\hat{z}_{2 j}$. Thus, an individual is an employee if his/her ability $z_{j}$ is such that $z_{j} \in\left[\underline{z}_{j}, \hat{z}_{1 j}\right)$, which implies that the earnings from being either an own-account or an employer are lower than those from wage labor. In contrast, individuals with ability $z_{j} \in$ $\left[\hat{z}_{1 j}, \hat{z}_{2 j}\right)$ become own-account workers because the income obtained in such a case is higher than the income from the other two alternatives. Finally, full-time entrepreneurs

are those whose ability is such that $z_{j} \in\left[\hat{z}_{2 j}, \bar{z}_{j}\right]$. These two thresholds are unique because the profit functions $\pi_{j}\left(\cdot, z_{j}\right)$ and $\pi_{o j}\left(\cdot, z_{j}\right)$ are strictly increasing in entrepreneurial ability $z_{j}$.

For illustrative purposes, Figure 1 presents the earnings profile for employers, ownaccounts and employees as a function of ability in sector $j$. The thresholds levels $\hat{z}_{1 j}$ and $\hat{z}_{2 j}$ are denoted by $z 1$ and $z 2$, respectively, in Figure 1.

Given the discussion above, the budget constraint of the household may be written as follows:

$$
p_{1 t} C_{1 t}+C_{2 t}+I_{t}=\sum_{j \in\{1,2\}}\left\{\int_{\underline{z}_{j}}^{\hat{z}_{1 j}} W_{t} N_{t} g_{j}\left(z_{j}\right) d z_{j}+\int_{\hat{z}_{1 j}}^{\hat{z}_{2 j}}\left[\pi_{o j}\left(\cdot, z_{j}\right)+T_{I t}\right] g_{j}\left(z_{j}\right) d z_{j}+\int_{\hat{z}_{2 j}}^{\bar{z}_{j}}\left[\pi_{j}\left(\cdot, z_{j}\right)+T_{I t}\right] g_{j}\left(z_{j}\right) d z_{j}\right\}+r_{t} K_{t},
$$

where $W_{t} N_{t} \equiv \eta_{t}\left(w_{F t}+T_{F t}\right)+\left(1-\eta_{t}\right)\left(w_{I t}+T_{I t}\right)$ is labor income.

\section{Household's first-order conditions and occupational choice}

The first-order condition regarding $\eta$ implies that the household arbitrages so that employees are indifferent between allocating labor to formal or informal activities according to 


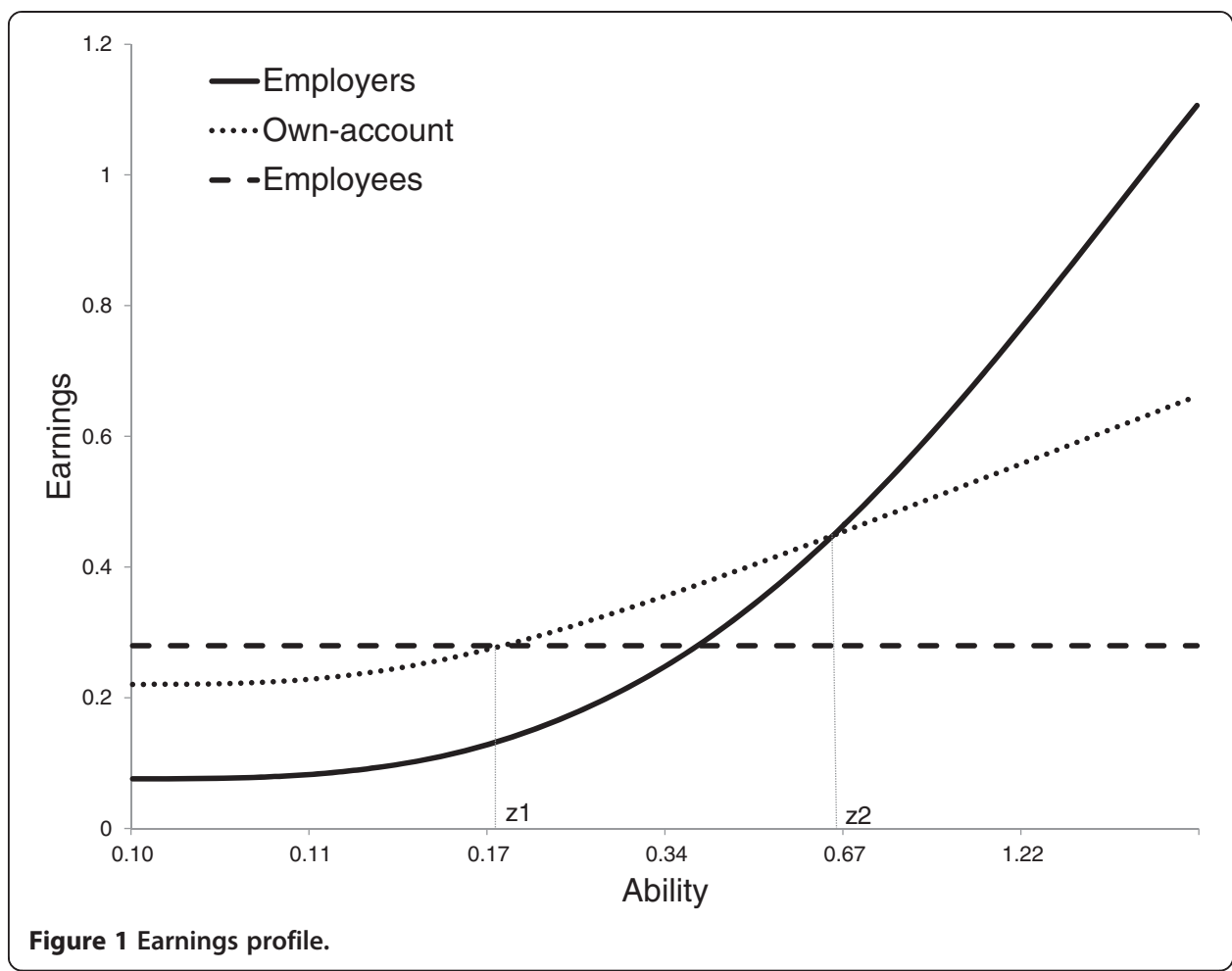

$$
w_{F t}+T_{F t}=w_{I t}+T_{I t}
$$

The expression above resembles a free labor mobility condition across formal and informal employments. It also implies that formal and informal wages will differ as long as $T_{I} \neq T_{F}$ which depends, in turn, on the tax-cum-subsidies structure for social insurance and how each type of worker values such benefits (see below).

The first-order condition for $\hat{z}_{1 j}$ has the interpretation that a household member will be indifferent between being an employee or an own-account worker:

$$
w_{I t}=\pi_{o j}\left(\cdot, \hat{z}_{1 j}\right), j=1,2 .
$$

Given that the profit function $\pi_{o j}$ is strictly increasing in the ability level $z_{j}$, equation (9) uniquely defines the threshold level $\hat{z}_{1 j}$.

A member will also be indifferent between being an own-account or an employer for a threshold level $\hat{z}_{2 j}$, which satisfies

$$
\pi_{o j}\left(\cdot, \hat{z}_{2 j}\right)=\pi_{j}\left(\cdot, \hat{z}_{2 j}\right), j=1,2 .
$$

\section{Worker's valuation of social transfers}

If a household employee allocates labor to formal activities, he/she gets paid the formal wage $w_{F}$ and receives CSI benefits that cost $\tau_{l} w_{F}$. Following Levy (2008) and Antón et al. (2012), the value these workers assign to such benefits is captured by the parameter $\beta_{F} \in[0,1]$. Therefore, the transfer $T_{F}$ may be expressed as $T_{F}=\beta_{F} \tau_{l} w_{F}$. The wage rate after transfers is thus given by $w_{F}+T_{F}=w_{F}\left(1+\beta_{F} \tau_{l}\right)$. The difference between what firms pay per formal worker, $w_{F}\left(1+\tau_{l}\right)$, and the benefits received, $w_{F}\left(1+\beta_{F} \tau_{l}\right)$, is 
in fact a "pure tax" (see, for example, Auerbach and Kotlikoff, 1987, and Feldstein and Samwick, 1998).

It is also assumed that informal workers do not value fully the benefits they get from NCSI. These workers are paid the informal wage $w_{I}$ and receive NCSI benefits in a lump sum fashion. Let $\beta_{I} \in[0,1]$ capture the value such workers give to NCSI and $\tau_{N C S I}$ capture the amount spent on NCSI per informal worker. Accordingly, the wage rate after transfers is $w_{I}+T_{I}=w_{I}+\beta_{I} \tau_{N C S I}$.

\section{Steady-state equilibrium}

Market-clearing conditions are required for labor, capital, and goods markets. As for equilibrium in the labor market, let $N^{*}$ denote aggregate labor supply, where an (*) over a variable denotes its equilibrium value at steady-state. Using the steady-state version of (8), labor supply may be written as

$$
N^{*} \equiv \sum_{j}\left\{G_{j}\left(\hat{z}_{1 j}^{*}\right)+\kappa \int_{\hat{z}_{1 j}^{*}}^{\hat{z}_{2 j}^{*}} g_{j}\left(z_{j}\right) d z_{j}\right\} \text {. }
$$

The first term on the right side of (11) is the mass of employees, and the second term is the labor supplied by the own-account. Equilibrium in the labor market may be thus denoted by

$$
N^{*}=\sum_{j}\left\{\int_{\hat{z}_{1 j}^{*}}^{\hat{z}_{2 j}^{*}} l_{o j}\left(w_{F}^{*}, r^{*}, p_{1}^{*}, z_{j}, \tau_{j}\right) g_{j}\left(z_{j}\right) d z_{j}+\int_{\bar{z}_{2 j}^{*}}^{\bar{z}_{j}} l_{j}\left(w_{F}^{*}, r^{*}, p_{1}^{*}, z_{j}, \tau_{j}\right) g_{j}\left(z_{j}\right) d z_{j}\right\} .
$$

Similarly, market clearing in the market for capital services may be written as

$$
K^{*}=\sum_{j}\left\{\int_{\hat{z}_{1 j}^{*}}^{\hat{z}_{2 j}^{*}} k_{o j}\left(w_{F}^{*}, r^{*}, p_{1}^{*}, z_{j}, \tau_{j}\right) g_{j}\left(z_{j}\right) d z_{j}+\int_{\hat{z}_{2 j}^{*}}^{\bar{z}_{j}} k_{j}\left(w_{F}^{*}, r^{*}, p_{1}^{*}, z_{j}, \tau_{j}\right) g_{j}\left(z_{j}\right) d z_{j}\right\}
$$

Finally, the resource constraint yields the equilibrium condition in the goods market:

$$
p_{1}^{*} C_{1}^{*}+C_{2}^{*}+I^{*}=p_{1}^{*} Y_{1}\left(\tau, w_{F}^{*}, r^{*}, p_{1}^{*}\right)+Y_{2}\left(\tau, w_{F}^{*}, r^{*}, p_{1}^{*}\right),
$$

where

$$
Y_{j}\left(\tau, w_{F}^{*}, r^{*}, p_{1}^{*}\right) \equiv \int_{\hat{z}_{1 j}^{*}}^{\hat{z}_{2 j}^{*}} y_{o j}\left(\cdot, z_{j}\right) g_{j}\left(z_{j}\right) d z_{j}+\int_{\hat{z}_{2 j}^{*}}^{\bar{z}_{j}} y_{j}\left(\cdot, z_{j}\right) g_{j}\left(z_{j}\right) d z_{j}
$$

is total output in sector $j$.

After substituting equation (11) into (12), the new expression along with (13) and (14) define a three-equation system that solves for the set of prices $\left\{w_{F}^{*}, r^{*}, p_{1}^{*}\right\}$, given the tax/subsidy policy vector $\tau=\left(\tau_{1}, \tau_{2}, T_{F} T_{I}\right)$ and density functions for managerial ability in each sector $j$. The informal wage rate at equilibrium, $w_{I}^{*}$, may be obtained from the steady-state version of (8) after substituting the equilibrium wage rate $w_{F}^{*}$.

Now it is illustrative to examine the effects of a fall in payroll taxes on occupational choices. For that purpose, refer again to Figure 1. A fall in $\tau_{l}$ translates into an increase in the equilibrium wage rate $w_{F}^{*}$. The magnitude of such an increase depends on the pass- 
through effect. From (8), the informal wage rate $w_{I}^{*}$ also rises. This shifts the earnings profile of employees upwards in Figure 1. Suppose for a moment that the earnings of both own-account and employers do not change. Then the threshold level $\hat{z}_{1}$ moves to the right, and thus the number of employees increases as a result of the fall in $\tau_{l}$. In practice, the effects are more complex. The increase in the equilibrium wage rates changes the earnings profile of both the own-account and employers. Therefore, the final effect of a fall in the payroll tax on the thresholds $\hat{z}_{1}$ and $\hat{z}_{2}$ is ambiguous in general. For the tax reform exercises shown below, the number of employees increases, indicating that $\hat{z}_{1}$ moves to the right after a fall in $\tau_{l}$. At the same time, formal employees increase relatively more than informal employees, given the fall in the relative cost of formal workers.

The model may be now used to evaluate the impact of the Colombian tax reform on labor markets. For such a purpose, two reform scenarios are considered. In the first, the payroll tax $\tau_{l}$ is decreased by $13.5 \mathrm{pp}$, and the CIT $\tau_{i}$ is left unchanged. This assumption reflects the introduction of the 8 percent "fairness tax" and the simultaneous decrease in the CIT from 33 to 25 percent already mentioned in section 3 . The second scenario also considers a fall of $13.5 \mathrm{pp}$ in $\tau_{l}$ but an increase in $\tau_{i}$ from 33 to 34 percent, given the temporary raise to 9 percent in the "fairness tax". In these two scenarios, the VAT rates do not change, reflecting the assumption that the tax reform related to the VAT would not bring a change in the VAT effective rates at the aggregate level.

\section{Calibration}

This section describes data sources, the explicit functions used in the model, and how parameters values are set as a previous step to the discussion of results. In particular, the model is calibrated to match key features of the Colombian data previous to the fiscal reform approved on December, 2012. Unless otherwise noted, the reference year is either 2011 or 2012, depending on the data availability.

\section{Data}

Data on employment, formality status, establishment size, and government taxes and transfers are collected from a number of sources. Goods and services in each sector are classified at the four-digit level using the International Standard Industrial Classification of All Economic Activities Rev. 3 Adapted for Colombia (ISIC Rev. 3 A. C.). A four-digit classification is used because it is the most detailed level for which the household survey data required to compute employment figures is available.

Employment data are taken from the household survey Gran Encuesta Integrada de Hogares (GEIH) for the second quarter of 2012. Government employees are excluded from the data because the model relates to optimal choices of private agents. After making such an adjustment, the total occupied labor force is 20.1 million workers. Using the same data source, the fraction of workers in sector 1 is 25.2 percent. GEIH also provides information to estimate the fraction of own-account workers per sector and the shares of formal and informal salaried workers. Here, a salaried employee is formal if he/she is affiliated to a contributory health system (Entidades Promotoras de Salud) and simultaneously contributes to a pension fund. Otherwise the worker is informal. Of course, alternative definitions of formality are possible, for example if the worker contributes to only health or pensions. As discussed in Bernal (2009) for the case of Colombia, these alternative definitions of formality are highly correlated with the definition here adopted. 
Data related to establishment size are collected from the 2005 General Census, which is the most recent economic census available for Colombia. Both workers and establishments are allocated to each sector using the ISIC Rev. 3 A. C. at the four-digit level.

VAT revenue data, as a share of GDP, is collected from the Ministry of Finance. The 2011 figures are used because data for 2012 is still preliminary. NCSI transfers include government spending on health and pensions for informal workers. Data on spending allocated to the subsidized health system and the non-affiliated poor population is taken from Barón (2012). For pensions, spending on the Fondo de Solidaridad Pensional (mutual pension fund) is considered using the information from the Ministry of Finance. Budget figures are used because current information is not easily available.

\section{Explicit functions}

Particular functions must be specified for the model to be solved. The utility function $u$ $\left(C_{1 t}, C_{2 t}\right)$ satisfies the standard CES form:

$$
u\left(C_{1 t}, C_{2 t}\right)=\left[v C_{1 t}^{\phi}+(1-v) C_{2 t}^{\phi}\right]^{1 / \phi} .
$$

Here, $v \in(0,1)$ is the weight of good $C_{1}$ in the consumption composite, and $1 /(1-\phi)$ is the elasticity of substitution between consumption goods with $\phi<1$.

A distribution function for entrepreneurial ability in each sector is also needed. Following Leal (2014), it is assumed that such ability follows a truncated Pareto distribution of the form

$$
G_{j}\left(z_{j}\right)=\frac{1-\left(\frac{z_{\text {, min }}}{z_{j}}\right)^{S_{j}}}{1-\left(\frac{z_{j, \text { min }}}{z_{\text {j,max }}}\right)^{S_{j}}},
$$

where $S_{j}>0$ is a shape parameter associated with the distribution in sector $j, z_{j, m i n} \equiv \underline{z}_{j}$ and $z_{j, \max }=\bar{z}_{j}$ for each $j$.

The functional forms for the probability of detection in VAT and CSI taxes are assumed linear in the ability level $z_{j}$. This implies setting $q_{y j}\left(z_{j}\right)=\bar{\lambda}_{j}^{V A T} z_{j}$ and $q_{l j}\left(l_{I j}, z_{j}\right)=\bar{\lambda}_{j}^{C S I} l_{I j} z_{j}$, where $\bar{\lambda}_{j}^{V A T}$ and $\bar{\lambda}_{j}^{C S I}$ are positive parameters. In the calibration exercise below, these parameters are set the same across sectors, so that $\bar{\lambda}_{1}^{V A T}=\bar{\lambda}_{2}^{V A T}$ and $\bar{\lambda}_{1}^{C S I}=\bar{\lambda}_{2}^{C S I}$.

\section{Parameter values}

The parameters needed to calibrate the model include those related to preferences, technology, enforcement, and the distribution of abilities. Parameters are divided in two groups: group 1 includes all the parameters that are calibrated independently, and group 2 includes those that are calibrated jointly. That is, given the value of the parameters in group 1, the steady-state equilibrium is solved and the value of the parameters in group 2 is set to match relevant moments in the Colombian data. The values for some parameters in group 1 are either taken from the literature or set a priori, as specified below; all the remaining parameters are set to match Colombian data.

Parameters in group 1 whose values are either taken from the literature or set $a$ priori include $\kappa, \alpha, \delta, \beta$ and $\phi$. Following Gollin (2008), the parameter $\kappa$ is set at 0.4, 
which implies that own-account workers allocate 40 percent of their available time to entrepreneurial abilities. The capital share in the production function is fixed at the standard value of 0.33 (see, for example, Gonzalez et al. 2011, for the Colombian case). In the model, the capital share is expressed as $(1-\alpha) \gamma$. Given a value for $\gamma, \alpha$ is fixed so that $(1-\alpha) \gamma$ is equal to 0.33 . The annual depreciation rate $\delta$ is set at the standard value of 0.10 used in the business cycle literature. The discount factor $\beta$ is fixed at 0.96 so that the steady-state rate of return of capital is 4 percent. An estimate for the degree of substitution between the consumption goods associated with the taxed and untaxed sectors is not available in the literature. Instead, the Cobb-Douglas case is considered, and so $\phi$ is set to zero in equation (16).

Parameters in group 1 that are set according to the evidence from Colombian data include $\tau_{i}, \tau_{y j}, \tau_{l}, \sigma_{y}, \sigma_{l}, \beta_{I}$ and $\beta_{F}$. The CIT $\tau_{i}$ is set at the statutory value of 33 percent that was in place before the 2012 fiscal reform. As for the VAT, the system in Colombia is complex. Previous to the 2012 reform, there were 7 tax rates for the VAT: 0, 1.6, 10, 16, 20, 25 and 35 percent. To simplify, goods and services taxed at 0 and 1.6 percent are included in the "non-tax" sector of the model. Exempt goods and services are also included in this category. All other goods and services are included in the "taxed" sector, where the general VAT rate of 16 percent is assumed. Accordingly, $\tau_{y 1}=0$ and $\tau_{y 2}=0.16$.

The payroll tax as a percentage of the wage rate is constructed according to the components listed in Table 1. By law, all the components in Table 1 are paid by the employer, with the exception of pensions and health care. In those cases, the employee contributed 4 of the $16 \mathrm{pp}$ for pensions and 4 of the $12.5 \mathrm{pp}$ for health care. Professional risks vary between 0.348 and 8.7 percent of the wage, depending on the job task. Here, the average rate of 2 percent reported in Vargas (2006) is used. Figures for paid vacations, severance pay and mandatory bonuses are taken from Hernández (2012).

The penalty imposed on VAT evaders varies widely according to the Colombian Tax Code and depends on a series of factors. For simplicity, penalties are simply set to 150 percent of the amount evaded, which implies $\sigma_{y}=1.5$. A similar number is set for penalties imposed by the authority if a firm is caught evading payroll taxes; thus, $\sigma_{l}=1.5$. Taking the estimates of Cuesta and Olivera (2010) for Colombian data, the parameters related to the valuation of CSI and NCSI services, $\beta_{F}$ and $\beta_{I}$, are fixed to 0.48 and 0.525 , respectively.

Parameters in group 2 include the following: $\gamma, v, \bar{\lambda}_{1}^{V A T}, \bar{\lambda}_{1}^{C S I}, \tau_{N C S I}, A_{o, 1}, A_{o, 2}, \bar{z}_{1}, \bar{z}_{2}, S_{1}$ and $S_{2}$. These 11 parameters are set to match 11 moments in the data. The moments and their data values are listed in the first and second columns of Table 2. Potential VAT revenue in Table 2 is defined as the revenue collected in the absence of evasion, given the tax structure for the VAT. It is estimated as the average for the period of 2000-2007 by using the information provided by Cruz (2009). NCSI spending on health is estimated at 1.5 percent of GDP in 2011 (Barón, 2012), whereas pension spending amounts to 0.12 percent of GDP. Using these two estimates, NCSI transfers are set at 1.62 percent of GDP.

The results of the calibration strategy for the parameters in group 2 are presented in the third column of Table 2. In general, the model is able to replicate most of the moments quite well. The only exception is the fraction of employment in establishments with more than 50 workers in sector 2 , but the difference between the data and the model is not substantial.

If employment is defined in terms of salaried plus own-account workers, the ownaccount workers constitute 41 percent of the total employment in the calibrated model. 
Table 2 Comparing moments in the model and the data

\begin{tabular}{|c|c|c|}
\hline Moment & Data & Model \\
\hline \multicolumn{3}{|c|}{ Establishment size and employment distributions } \\
\hline Mean size sector 1 & 10.14 & 10.11 \\
\hline Mean size sector 2 & 6.15 & 6.18 \\
\hline Mean size, +50 sector 1 & 174.21 & 174.05 \\
\hline Mean size, +50 sector 2 & 191.89 & 191.25 \\
\hline Employment share, +50 in sector 2 & 0.27 & 0.21 \\
\hline \multicolumn{3}{|c|}{ Informality } \\
\hline Share of own-account in sector 1 & 0.34 & 0.34 \\
\hline Share of own-account in sector 2 & 0.38 & 0.39 \\
\hline Share of informal salaried workers & 0.39 & 0.40 \\
\hline \multicolumn{3}{|c|}{ Other Aggregates } \\
\hline VAT Revenue/GDP & 0.057 & 0.057 \\
\hline Potential VAT Revenue/GDP & 0.077 & 0.077 \\
\hline NCSI subsidies/GDP & 0.016 & 0.016 \\
\hline
\end{tabular}

This implies that the remaining 59 percent are salaried workers, of which 35 percent are formal and 24 are informal. According to this classification, salaried workers in the model not only include the salaried employees in the data but also housekeeping workers and all unpaid workers in establishments with more than one person. Interestingly, a 35 percent share of formal workers in the model is well within the estimates reported by Bernal (2009) and Mondragón-Vélez et al. (2010) for Colombia.

\section{Results}

Main results

Once all the parameters in the model are set, the model is used to evaluate the effects of the recent fiscal reform in Colombia (Law 1607, 2012) on labor markets, in particular the reforms related to the change in the source of financing for training (SENA program), in-kind transfers to low-income households (ICBF program), and employer's contributions to health care. As already mentioned, two reform scenarios are considered. Scenario A assumes a decrease of $13.5 \mathrm{pp}$ in payroll taxes and leaves the CIT rate constant at its statutory value of 33 percent. To compensate for the fall in transfers $T_{F}$ it is also assumed that formal workers now receive a non-wage based, lump-sum transfer equivalent to 9 percent of their benchmark wage rate. This 9 percent includes 2 percent from SENA and 7 percent from the employer's contributions to health care, given that the remaining $1.5 \mathrm{pp}$ were transferred to the non-contributory system (FOSYGA's mutual account) previous to the fiscal reform. In-kind transfers are not included in the lump-sum transfer $T_{F}$ because they are not designed to provide direct benefits to formal workers. Scenario B includes scenario A plus an increase in the CIT rate to 34 percent.

The results of such exercises on employment and real earnings are provided in Table 3. Under scenario A, total employment increases by 0.3 percent over the 
benchmark. This number is explained by a 3.7 and 0.9 percent increase in formal and informal salaried employment, respectively, and a fall of 4.3 percent in own-account employment. The intuition is relatively simple: the reform makes salaried labor cheaper and thus increases the demand for salaried workers at the expense of own-account workers. Therefore, the model suggests a large reallocation of labor across occupations and formality status as a result of the reform and a small positive impact on total employment ${ }^{17}$.

In terms of earnings, the model finds a fall of 4 percent in the equilibrium gross wage rate for formal workers under Scenario A. This result is consistent with the discussion above and the goals of the reform itself, namely, a fall in the cost of salaried formal workers. At the same time, the formal wage rate net of taxes and subsidies increases by 4.9 percent. Such a fall suggests the presence of a large pass-through effect, as discussed in Section 2. The informal wage rate also increases in both gross and net terms, given that workers are free to move between formal and informal occupations (see equation 8). However, the net increase is lower if compared to that registered for the formal net wage. Employers' profits are also higher on average, which is partially due to the fall in payroll taxes. The earnings of the own-account workers are also higher on average, which follows the increase in the informal wage (see equation 9) and the lower number of own-account workers after the reform. Overall, Scenario A suggests that formal salaried workers would be the most benefited in terms of earnings on average.

Table 3 also presents the results under scenario B. The increase in employment is 0.5 percent, with respect to the benchmark case. With the exception of employer's earnings, the estimated changes are lower in absolute value if compared to scenario A. The change in both formal and informal salaried employment is lower because labor demand depends negatively on the CIT. At the same time, the increase in the CIT encourages some employers to become own-account workers. This explains why the fall in own-account employment is lower if compared to Scenario A. Notably, the

Table 3 Fiscal reform effects on employment and real earnings (percentage change with respect to the benchmark)

\begin{tabular}{|c|c|c|}
\hline & Reform scenario A & Reform scenario B \\
\hline \multicolumn{3}{|l|}{ Employment } \\
\hline Total employment ${ }^{(a)}$ & 0.3 & 0.5 \\
\hline Salaried formal & 3.7 & 3.4 \\
\hline Salaried informal & 0.9 & 0.5 \\
\hline Own-account & -4.3 & -3.4 \\
\hline \multicolumn{3}{|l|}{ Real earnings } \\
\hline Formal gross wage & -4.0 & -4.0 \\
\hline Formal net wage ${ }^{(b)}$ & 4.9 & 4.8 \\
\hline Informal gross wage & 2.9 & 2.8 \\
\hline Informal net wage $\mathrm{e}^{(\mathrm{b})}$ & 3.0 & 2.9 \\
\hline After-tax average earnings, own-account & 2.8 & 2.6 \\
\hline After-tax average earnings, employers & 4.0 & 4.6 \\
\hline
\end{tabular}

Notes:

(a) Salaried plus own-account workers.

(b) Net of taxes/subsidies.

Reform scenario A assumes a fall of 22.4 percent in labor taxes (equivalent to a decrease of 13.5 percentage points) and a lump-sum transfer to formal workers equivalent to 9 percent of their benchmark wage rate.

Reform scenario B assumes scenario A plus an increase in the corporate income tax rate from 33 to 34 percent. 
change in formal and informal wages is roughly the same as before. However, employer's average earnings increase further even though the CIT is higher. This result is mostly explained by the smaller number of employers under scenario B. Nevertheless, formal salaried workers are still those who get the largest increase in earnings after the reform.

For illustrative purposes, the effects of the fiscal reform on government revenue as a share of GDP are shown in Table $4^{18}$. Under Scenario A, total revenue decreases by $0.32 \mathrm{pp}$ compared to the benchmark scenario. This result is explained by a fall of $67 \mathrm{pp}$ in the payroll tax. Interestingly, both the VAT and the CIT increase slightly by 0.23 and $0.12 \mathrm{pp}$, respectively, even though their corresponding tax rates are kept constant under Scenario A. This result suggests that the increase in labor formality as a result of lower payroll taxes increases the tax base for other revenue sources (cfr. Antón et al. 2012). The decrease in total revenue under Scenario B is roughly similar to the previous case. However, the relative importance of each tax to explain this fall changes. Naturally, the increase in CIT revenue is larger ( $0.21 \mathrm{pp}$ ) because such a tax increases from 33 to 34 percent. However, the payroll tax falls even further because the tax hike decreases the number of formal workers. Overall, the results from Table 4 suggest that the fiscal reform considered here might yield a modest fall in government revenue.

\section{Sensitivity analysis}

The next step is to perform a sensitivity analysis of the results provided in Table 3 . Particular attention is given to alternative values for the valuation of CSI and NCSI services under Scenario A. The estimates are shown in Table 5. For each of the alternative scenarios, the parameter under consideration is initially set at some given value, but the rest of parameters in group 1 remain unchanged. At the same time, parameters $\tau_{N C S I}, A_{o, 1}, A_{o, 2}, \bar{z}_{1}, \bar{z}_{2}, S_{1}$, and $S_{2}$ in group 2 are calibrated as discussed in the previous section. Once the model is recalibrated under the new benchmark, Scenario A is simulated. Therefore, the percentage changes reported in Table 5 are measured over their corresponding steady-state values under the new benchmark. For convenience, the first column of results simply replicates those reported in Table 3.

The first exercise assumes a lower valuation of CSI services by decreasing the parameter $\beta_{F}$ from 0.48 to the arbitrary value of 0.25 . For a given wage rate, this implies a larger wedge between the cost to firms per formal worker and the actual benefits received from formal social insurance. As before, the lower payroll tax makes salaried labor cheaper. However, now informal salaried work is more attractive because CSI services are less valuable. This explains why the change in salaried informal and own-

Table 4 Fiscal reform effects on government revenue ${ }^{(a)}$ (percentage point change with respect to the benchmark)

\begin{tabular}{lcc}
\hline & Reform scenario A & Reform scenario B \\
\hline Total revenue & -0.32 & -0.31 \\
Value-added tax & 0.23 & 0.19 \\
Corporate income tax & 0.12 & 0.21 \\
Payroll (CSI) tax & -0.67 & -0.71 \\
\hline $\begin{array}{l}\text { Notes: } \\
\text { (a) As a share of GDP. }\end{array}$ & &
\end{tabular}


Table 5 Sensitivity analysis (percentage change with respect to the benchmark)

Reform scenario A Scenario A under lower

under benchmark valuation of CSI services

Scenario A under higher valuation of CSI services

Scenario A under higher valuation of NCSI transfers

Scenario A under higher enforcement of payroll taxes

\section{Employment}

Total employment

Salaried formal

Salaried informal

Own-account

$\begin{array}{cc}0.3 & 0.2 \\ 3.7 & 3.5 \\ 0.9 & 1.5 \\ -4.3 & -4.8\end{array}$

\section{Earnings}

Formal gross wage

Formal net wage ${ }^{(b)}$

Informal gross wage

Informal net wage ${ }^{(\mathrm{b})}$

After-tax average earnings, own account

After-tax average earnings, employers

Notes:

(a) Salaried plus own-account workers.

(b) Net of taxes/subsidies.

Reform scenario $A$ assumes a fall of 22.4 percent in labor taxes (equivalent to a decrease of 13.5 percentage points) and a lump-sum transfer to formal workers equivalent to 9 percent of their benchmark wage rate.

See the main text for an explanation of each scenario. 
account employment is higher in absolute value. This is also reflected in a larger increase in the informal wage rate.

The second exercise examines the opposite case, i.e., a higher valuation of CSI services. Now $\beta_{F}$ is increased from 0.48 to the arbitrary value of 0.75 . The results are listed in the third column of Table 5. As expected, the increase in formal employment is even higher (5.1 percent). Given that the increase in total employment is not of a similar magnitude, the fall in salaried informal plus own-account employment is also larger. Interestingly, salaried informal labor now falls by 1.3 percent, which decreases the adjustment in ownaccount employment. Moreover, the gap in the change between formal and informal net wages is larger (5.3 vs. 2.7 percentage change), if compared to the benchmark case.

To examine the sensitivity of results to the valuation of transfers to informal workers, $\beta_{I}$ is increased from its benchmark value of 0.525 to 0.75 . The results are listed in column four. After comparing these results with those from column one, this exercise suggests that the simulations are not particularly sensitive to the valuation of NCSI transfers.

The last simulation performs a slightly different exercise. Taking the original benchmark calibration, the simulation assumes that Scenario A is implemented along with an increase in the enforcement of payroll taxes. In particular, the parameter $\bar{\lambda}_{1}^{C S I}$ is arbitrarily multiplied by 1.1. The results are provided in the last column of Table 5 . They are roughly the same as those reported in the first column, with the exception of salaried employment. In particular, a higher enforcement of payroll taxes increases the positive effect of the reform on formal employment at the expense of informal salaried employment.

Overall, the exercises listed in Table 5 suggest that the results reported in Table 3 are generally robust to alternative parameterizations. Therefore, the previous finding that the fiscal reform would have a positive and small effect on total employment but a large effect on the reallocation of workers across occupations and formality status remains.

\section{Conclusion}

This paper has evaluated the effects of the 2012 fiscal reform in Colombia on labor markets through the lens of a dynamic, general equilibrium model with occupational choice and informality. As already explained, the fiscal reform involved a significant decrease in payroll taxes and a partial shift in the tax base from labor to corporate income to finance social programs. The model has been calibrated for the Colombian economy, which, as is typical in developing countries, is characterized by high labor informality. The results suggest that the reform would have a modest effect on employment but a significant reallocation of labor across occupations and formality status. In particular, as a result of the reform, total employment would increase between 0.3 and 0.5 percent. Correspondingly, formal employment would rise between 3.4 and 3.7 percent, and informal employment would decrease between 2.9 and 3.4 percent. The reform would also bring an increase in the net wage for formal workers between 4.8 and 4.9 percent. This last result suggests that there is a large pass-through effect in the Colombian labor market, so that the fall in payroll taxes may translate into higher wages for formal workers.

An issue that must be kept in mind is that the exercises reported here assume no further changes in the tax and transfer policy. In the model, the household decision to allocate labor to formal or informal activities depends crucially on the tax and transfer scheme. For example, an increase in non-contributory transfers to informal workers 
may have a sizable effect in the reallocation from formal to informal labor. Recent work by Antón et al. (2012) and Alonso-Ortiz and Leal (2013) shows that both the size and distribution of government transfers between formal and informal workers may have a significant effect on informality. In this regard, if the Colombian fiscal reform is aimed at increasing labor formality, it is important to guarantee that the scheme of taxes and transfers in the near future will be "dynamically consistent". Otherwise, a fiscal reform that is accompanied by an increase in transfers to informal workers in the medium term might end up taking the economy back to its pre-reform levels of informality.

One additional aspect for assessing the 2012 Colombian tax reform is its effect on income distribution given the interest of the government authorities to decrease income inequality. Unfortunately, the present model cannot be used to examine this issue because there is no heterogeneity in labor income by construction: in equilibrium, all formal and informal salaried workers end up earning the same wage rate. In this regard, models along the lines of Albrecht et al. (2009) and Bosch and EstebanPretel (2012), among others, might be well suited to examine such effects. Another issue that deserves further analysis is how the presence of a binding minimum wage might affect the results presented here. This is especially important given the evidence that the minimum wage is binding in Colombia (see, for example, Bell, 1997, and Maloney and Méndez, 2004). The model considered here does not impose a minimum wage restriction on optimality conditions, and thus it is silent on this issue. At the same time, the model yields full employment in equilibrium. Therefore, a model featuring unemployment and a binding minimum wage would shed further light on the labor market effects of the Colombian tax reform.

\section{Endnotes}

${ }^{1}$ See, for example, Schneider and Enste (2000) for a detailed review on this issue.

${ }^{2}$ As detailed in section 3, the 2012 Colombian tax reform involved a series of changes in other taxes as well, mainly on corporate income and value-added taxes. However, the reform was designed so that the effective tax rates on these two taxes at the aggregate level remained roughly unchanged. For example, as mentioned above the tax base for the financing of social programs was partially shifted from labor to corporate income. To avoid increasing the firms' tax burden, the corporate income tax was decreased proportionally so that the effective tax rate remained approximately unchanged after the reform. In terms of effective tax rates, only the payroll tax was significantly changed as a result of the reform.

${ }^{3}$ For a recent and detailed review of the literature, the reader is referred to Kugler (2011).

${ }^{4}$ Betcherman et al. (2010) study the effects of subsidies to payroll taxes, personal income taxes, energy consumption and land on registered employment and establishments in Turkey. The amount of the subsidies is based on a series of requirements at the firm level. Their findings suggest an increase of between 5 and 15 percent in registered employment. The evidence also suggests that the subsidies would increase registration by firms and workers rather than boosting total employment.

${ }^{5}$ The TJTC program reduced taxes for the first $\$ 6,000$ of wages for disadvantaged individuals by 50 percent for the first year and by 25 percent for the second year after enrollment in the program. 
${ }^{6}$ The program was introduced in Spain in 1997 and targeted at permanent labor contracts. The subsidies granted were 40 percent for workers under 29 years old and 60 percent for workers over 45 years old.

${ }^{7}$ The authors recognize that having a plant reporting positive payroll taxes does not mean that all the workers in that particular plant are formal.

${ }^{8}$ According to the National Department of Statistics (DANE), a worker is informal if he/she has one of the following characteristics: 1) is an employee who works in establishments, businesses or private companies with 10 or fewer employees in all agencies and branches; 2) is an unpaid family worker or a domestic employee; or 3) is an own-account worker, with the exception of independent professionals and technicians.

${ }^{9}$ Parafiscales taxes are non-wage labor costs for the financing of social programs in Colombia. Before the 2012 fiscal reform, they accounted for 9 percent of the non-wage labor costs and were paid by the employer. These revenues were used by the government to finance training programs ( 2 percent), in-kind transfers for low-income households (3 percent) and family compensation funds (4 percent). As detailed below, the 2012 fiscal reform eliminated the first two parafiscales taxes but kept the family compensation funds at 4 percent of the wage rate.

${ }^{10}$ For example, either a larger elasticity in labor demand or supply increases the passthrough effect.

${ }^{11}$ The deficit was temporarily raised to 3 percent of GDP in 2010 as a result of the 2008 downturn in the global economy.

${ }^{12}$ With respect to the current CIT scheme, the "fairness tax" includes fewer tax deductions so that the tax base is slightly larger.

${ }^{13}$ With the exception of prepared food, this new tax applies to those goods that originally paid a tax rate higher than 16 percent before the reform was implemented. As a result, these goods end up paying roughly the same total tax rate (value-added plus consumption tax) after the reform. Overall, it is not at all clear whether the tax reform will translate into a higher effective tax rate at the aggregate level on value-added and sales of final goods.

${ }^{14}$ Another major change of the 2012 Colombian tax reform was the introduction of a "minimum alternative tax" (IMAN) on personal income. Under this new scheme, workers earning up to US $\$ 1,960$ per month will not pay personal income taxes. The tax rate gradually increases in general as personal income increases, up to a maximum rate of 27 percent. With this measure, the government expects to eliminate the regressive structure of the previous tax system where the effective tax rates for low income workers were higher than those for high income workers. Given the structure of the model discussed in the next section, the effect of such a change on labor markets cannot be appropriately addressed.

${ }^{15}$ These services are contributory in the sense that a payroll tax is required for their funding.

${ }^{16}$ In the model, a tax on profits is equivalent to a lump sum tax.

${ }^{17}$ Because the share of formal workers in the model is 35 percent, the estimated percentage change in formal employment is 10.6 percent $(=3.7 / 0.35)$. Similarly, the percentage change in own-account employment is -10.5 percent $(=-4.3 / 0.41)$.

${ }^{18}$ In the model, the government must satisfy its budget constraint each period. The revenue fall observed in Table 4 is compensated through lower transfers in equilibrium. 
This is the case because the number of informal workers after the reform is lower, which decreases the amount of NCSI transfers.

\section{Abbreviations}

pp: Percentage points; VAT: Value-added tax; CSI: Contributory social insurance; CIT: Corporate income tax; NCSI: Non-contributory social insurance; GElH: Gran Encuesta Integrada de Hogares (National Household Survey); ISIC: International Standard Industrial Classification; SENA: Servicio Nacional de Aprendizaje (National Training Service); ICBF: Instituto Colombiano de Bienestar Familiar (Colombian Family Welfare Institute); CREE: Contribución Empresarial para la Equidad (Fairness Tax on Firms); FOSYGA: Fondo de Solidaridad y Garantía (Mutual Account for Health Services).

\section{Competing interests}

This research was sponsored by The World Bank (WB). It was neither financed nor sponsored by the Government of Colombia or any other government entity. The WB was not involved in the elaboration of the document, including the results of the paper. The WB did not finance any type of submission fee or article processing charge to the IZA Journal of Labor and Development. The WB was not involved in the decision to submit the manuscript for publication. I am not a WB employee. I am not applying for any patents relating to the content of the manuscript. I do not have any other financial competing interests. I also do not have any non-financial competing interests (political, personal, religious, ideological, academic, intellectual, commercial or any other) to declare in relation to this manuscript. The IZA Journal of Labor \& Development is committed to the IZA Guiding Principles of Research Integrity. The author declares that he has observed these principles.

\section{Acknowledgments}

This research was sponsored by The World Bank. The author gratefully acknowledges the editor and an anonymous referee for helpful comments. The author also thanks Barbara Cunha, Kaniska Dam, Lea Giménez, Luis Felipe López-Calva, Carlos Rodríguez and participants at the World Bank seminar for their suggestions. Valeria Durán provided outstanding research assistance. The usual disclaimer applies.

Responsible editor: Hartmut Lehmann

Received: 30 May 2014 Accepted: 13 October 2014

Published: 27 Nov 2014

\section{References}

Albrecht J, Navarro L, Vroman S (2009) The effects of labour market policies in an economy with an informal sector. Econ J 119:1105-1129

Alonso-Ortiz J, Leal J (2013) The Elasticity of Informality to Taxes and Transfers. Working Paper 13-08, Centro de Investigación Económica, ITAM, Mexico City, Mexico

Antón A, Hernández F, Levy S (2012) The End of Informality in Mexico? Fiscal Reform for Universal Social Insurance. Inter-American Development Bank, Washington, D. C.

Auerbach A, Kotlikoff L (1987) Dynamic Fiscal Policy. Cambridge University Press, Cambridge

Barón G (2012) Gasto nacional en salud de Colombia: composición y tendencias 2004-2011. Accessed June 4, 2013 at http://eventos.aviatur.com.co/congresosistemasdesalud/agend.html

Bell LA (1997) The impact of minimum wages in Mexico and Colombia. J Labor Econ 15(S3):S102-S135

Bernal R (2009) The informal labor market in Colombia: identification and characterization. Revista Desarrollo y Sociedad 63:145-208

Bernal R, Cárdenas M (2003) Determinants of labor demand in Colombia: 1976-1996. In: Heckman J, Pagés C (ed) Law and Employment: Lessons from Latin America and the Caribbean. University of Chicago Press, Chicago

Betcherman G, Daysal NM, Pagés C (2010) Do employment subsidies work? Evidence from regionally targeted subsidies in Turkey. Labour Econ 17:710-722

Blanchard O, Wolfers J (2000) The role of shocks and institutions in the rise of European unemployment: the aggregate evidence. Econ J 110:C1-C33

Bosch M, Esteban-Pretel J (2012) Job creation and job destruction in the presence of informal markets. J Dev Econ 98:270-286

Cruces G, Galiani S, Kidyba S (2010) Payroll taxes, wages and employment: identification through policy changes. Labour Econ 17:743-749

Cruz A (2009) Evasión del impuesto al valor agregado (IVA) en Colombia: 2000-2008. Cuadernos de Trabajo 36, Dirección de Impuestos y Aduanas Nacionales, Bogotá, Colombia

Cuesta J, Olivera M (2010) Social security distortions onto the labor market. World Bank Policy Research Working Paper 5390, Washington, D.C.

Daveri F, Tabellini G, Bentolila S, Huizinga H (2000) Unemployment, growth and taxation in industrial countries. Econ Policy 15(30):47-104

Estrades C, Terra Ml (2011) Fighting informality in segmented labor markets: a general equilibrium analysis applied to Uruguay. Latin Am J Econ 48(1):1-37

Farné S, Rodríguez DA (2013) ¿Bajar los impuestos al trabajo genera empleo? Cuaderno de Trabajo 14, Universidad Externado de Colombia, Bogotá, Colombia

Feldstein M, Samwick A (1998) The transition path in privatizing social security. In: Feldstein M (ed) Privatizing Social Security. University of Chicago Press, Chicago

Gasparini L, Tornarolli L (2009) Labor informality in Latin America and the Caribbean: pattern and trends from household survey microdata. Revista Desarrollo y Sociedad 63:13-80

Gollin D (2008) Nobody's business but my own: self-employment and small enterprise in economic development. J Monet Econ 55:219-233 
González A, Ocampo S, Rodríguez D, Rodríguez N (2011) Asimetrías del empleo y del producto: una aproximación de equilibrio general. Borradores de Economía 663, Banco de la República, Bogotá, Colombia

Gruber J (1994) The incidence of mandated maternity benefits. Am Econ Rev 84:622-641

Gruber J (1997) The incidence of payroll taxation: evidence from Chile. J Labor Econ 15:S72-S101

Heckman J, Pagés C (2004) Introduction. In: Heckman J, Pagés C (ed) Law and Employment: Lessons from Latin America and the Caribbean. University of Chicago Press, Chicago

Hernández G (2012) Payroll taxes and the labor market: a computable general equilibrium analysis. Latin Am J Econ 49(1):99-123

Katz L (1998) Wage subsidies for the disadvantaged. In: Freeman R, Gottschalk P (ed) Generating Jobs. Russell Sage, New York

Kugler A (2011) Is there an anti-labor bias of taxes? A survey of the evidence from Latin America and around the world. Technical Note IDB-TN-299, Inter-American Development Bank, Washington, D.C.

Kugler A, Kugler M (2009) Labor market effects of payroll taxes in developing countries: evidence from Colombia. Econ Dev Cult Chang 57(2):335-358

Kugler A, Jimeno JF, Hernanz V (2002) Employment Consequences of Restrictive Permanent Contracts: Evidence from Spanish Labor Market Reforms. IZA Discussion Paper No. 657

Leal J (2014) Tax collection, the informal sector, and productivity. Rev Econ Dyn 17:262-286

Levy S (2008) Good Intentions, Bad Outcomes: Social Policy, Informality and Economic Growth in Mexico. Brookings Institution Press, Washington, D. C.

Lucas RE (1978) On the size distribution of business firms. Bell J Econ 9(2):508-523

Maloney W, Méndez J (2004) Measuring the impact of minimum wages. Evidence from Latin America. In: Heckman J, Pagés C (ed) Law and Employment: Lessons from Latin America and the Caribbean. University of Chicago Press, Chicago

Moller LC (2012) Fiscal Policy in Colombia: Tapping its Potential for a More Equitable Society. World Bank Policy Research Working Paper 6092, Washington, D.C.

Mondragón-Vélez C, Peña X, Wills D, Kugler A (2010) Labor market rigidities and informality in Colombia. Economia 11 (1):65-101

Organization for Economic Co-operation and Development (2013) OECD Economic Surveys: Colombia 2013: Economic Assessment. OECD Publishing, Paris

Schneider F, Enste DH (2000) Shadow economies: size, causes, and consequences. J Econ Lit 38(1):77-114

Summers LH (1989) Some simple economics of mandated benefits. Am Econ Rev 79(2):177-183

Vargas AJ (2006) The Labor Market Impacts of Social Security Contributions: Lessons from Colombia. Ph. D. dissertation. University of Texas at Austin, Austin, Texas

10.1186/2193-9020-3-20

Cite this article as: Antón: The effect of payroll taxes on employment and wages under high labor informality. IZA Journal of Labor \& Development 2014, 3:20

Submit your manuscript to a SpringerOpen ${ }^{\circ}$ journal and benefit from:

- Convenient online submission

- Rigorous peer review

- Immediate publication on acceptance

- Open access: articles freely available online

- High visibility within the field

- Retaining the copyright to your article

Submit your next manuscript at $\boldsymbol{\nabla}$ springeropen.com 